2017-09-18

\title{
A literature review on risk sources and resilience factors in agri-food supply chains.
}

\section{Zhao, G}

http://hdl.handle.net/10026.1/10208

All content in PEARL is protected by copyright law. Author manuscripts are made available in accordance with publisher policies. Please cite only the published version using the details provided on the item record or document. In the absence of an open licence (e.g. Creative Commons), permissions for further reuse of content should be sought from the publisher or author. 


\title{
A literature review on risk sources and resilience factors in agri-food supply chains
}

\author{
Guoqing Zhao, Shaofeng Liu, Carmen Lopez \\ University of Plymouth, Plymouth, Devon PL4 8AA, United Kingdom \\ \{guoqing.zhao, shaofeng.liu, carmen.lopez\}@plymouth.ac.uk
}

\begin{abstract}
Risk and uncertainty are ubiquitous and varied in agri-food supply chains. As environment volatility increases, only having capabilities to manage agri-food supply chain risks may not be enough, resilience factors also need to be integrated into daily operations. This paper undertakes a systematic literature review on risks sources and resilience factors in agri-food supply chains. A five-stage systematic review methodology has been followed. The findings suggest that agri-food supply chains are highly vulnerable to various risks due to its unique characteristics of products. Main risk sources include antibiotics resistance, weather related risks and natural disasters, policy and institutional risks, and unethical issues. Five key resilience factors identified from the literature are traceability, knowledge management, collaboration, culture, and agility. The paper makes a contribution to the extant literature in the field of agri-food supply chain risk management and agri-food supply chain resilience.
\end{abstract}

Keywords: Supply chain risks, Supply chain resilience, Inter-organisational knowledge management, Agri-food supply chains

\section{Introduction}

In the past few decades, there has been an increasing recognition that the world's agrifood supply chains have been experiencing major challenges due to an increasing level of globalization and innovation [21]. The increasingly important role of global agri-food supply chains was associated with increasing level of interconnectedness among suppliers, manufacturers and distributors, which resulted in higher dependency among entities in the supply chain as well as a higher level of complexity in the supply chain [8]. These resulted in the fact that agri-food supply chain can be running efficiently and effectively in the stable business environment, but are highly vulnerable to risks and disruptions in unstable business environment [21].

Agri-food supply chains have faced much unique vulnerability resulted from various types of risks; tackling these vulnerabilities may cause the increase of supply chain complexity and result in more instability and unpredictability [3], [18], [53]. As a result of the negative consequence of agri-food supply chain risks, researcher and academic have called for more research in this area, to design more efficient and resilient supply chains.

In order to address the risk and vulnerability issues, the concept of resilience has received great attention in recent years. Sullivan-Taylor and Branicki [44] argued that 
building resilience in agri-food supply chain is an emergency in the face of the climate change, soil degradation, pest outbreaks and population growth. Macfadyen et al. [24] suggested ten pieces of advice to improve agri-food supply chain resilience in their food supply system such as maintain soil resources, encourage sustainable practices in livestock management and protect water resources. Although the concept of supply chain resilience has been described by many researchers, there is no consensus on defining the construct. For some researchers, resilience is a capacity to withstand/adapt to disturbances, while others think resilience as a "dynamic capacity to continue to achieve goals despite disturbance and shocks" [24]. Therefore, the confusion around the concept is not surprising [27]. For now, we rely on the definition proposed by Tendall et al [45], which defined food system resilience as "capacity over time of a food system and its units at multiple levels, to provide sufficient, appropriate and accessible food to all, in the face of various and even unforeseen disturbances".

In this study, in order to operate agri-food supply chain efficiently and effectively, we aim to address two key questions about agri-food supply chains: (1) What are the main risk sources in the agri-food supply chains? (2) What are the key resilience factors that can be designed in an agri-food supply chain? In order to answer the above questions, the remainder of this paper is organised as follows. In section 2, we present a systematic literature review methodology. In section 3, we present several figures and tables to demonstrate the characteristics of the publications. In section 4, we provide a classification of risk sources in the agri-food supply chains. In section 5, an overview of resilience factors in the agri-food supply chains will be discussed. In section 6 , the main connections between resilience factors and risk sources will be discussed. Finally, conclusions are discussed in section 7.

\section{Review Methodology}

This paper is following the systematic literature review methodology proposed by Denyer and Tranfield [9]. A systematic literature review is an overview of primary studies that used in a clear and reproducible manner. This study follows the five phases systematic literature review proposed by Denyer and Tranfield [9]: (1) Define the research questions; (2) Location the studies; (3) Studies selection and evaluation; (4) Analysis and synthesis; and (5) Results presented. The method tries to assure that the process of the systematic literature review is transparent, reproducible and comprehensive.

\subsection{Define Research Questions}

The first phase in conducting a systematic literature review is to define research questions, which should clearly focus on risk sources and resilience factors in agrifood supply chains. The research questions were formulated based on the following process: (1) Brainstorming all the external and internal factors of an agri-food supply chain, and how the agri-food supply chain can be affected by the internal and external factors (2) Developing relevance trees to show the internal and external factors that 
have a positive effect on building agri-food supply chain resilience, and the factors that may be risk source of agri-food supply chains (3) Examining what might be possible approaches or strategies that can be used to reduce supply chain risks and enhance resilience?

\subsection{Locating Studies}

This phase is to consider which database is the most suitable to answer the research questions. Web of Science is a database that includes the global major journals and conference proceedings especially in Social Sciences, Arts and Humanities. Therefore, the Web of Science is identified as the source to search for relevant publications. In order to search for relevant publications, three groups of keywords were identified: (1) Words related to risk: risky, riskily, riskiness. We decided to use the term risk* to cover all possibilities; (2) Words related to resilience: resiliency, resilient; (3) Words related to agri-food supply chain: agriculture supply chain or food supply chain.

The comprehensive search of the Web of Science was based on all possible combination of group 1 and group 3 as well as group 2 and group 3. Only journals papers (articles and reviews) and conference proceedings were searched, limited to the areas of "operations research management science", "agricultural" and "food science technology" et al. We wanted to find state-of-art discussion on risk sources and resilience factors in the agri-food supply chains, therefore, we only consider the journal papers and conference proceedings published from 2000 and 2016. We consider the year 2003 as a turning point for research in supply chain resilience. This view is based on the result of literature review on enterprise and supply chain resilience by Kamalahmadi and Mellat Parast [21]. Their discovery indicates that there has been a sudden increase in the number of articles (supply chain resilience) published in 2004. We assumed that the papers published in 2004 were prepared in 2002 or 2003 after the "9/11" attacks in America, which damaged many supply chains across the globe. The initial search presented a total of 499 items.

\subsection{Study Selection and Evaluation}

After the initial search, then the articles were judged by the relevance of the abstract and the paper. The following criteria for inclusion or exclusion articles were used in this phase (Table 1). After this phase, 58 papers were selected for detailed analysis (Figure 1).

Table 1. Criteria for inclusion or exclusion papers

\begin{tabular}{ll}
\hline $\begin{array}{l}\text { First criterion: focus of the } \\
\text { abstract }\end{array}$ & $\begin{array}{l}\text { Abstracts focusing on risk sources in agri-food supply chains } \\
\text { or/and agri-food supply chain resilience have been included }\end{array}$ \\
$\begin{array}{l}\text { Second criterion: focus of } \\
\text { the papers }\end{array}$ & $\begin{array}{l}\text { Papers focusing on risk sources in agri-food supply chain } \\
\text { or/and agri-food supply chain resilience have been included }\end{array}$ \\
\hline
\end{tabular}


Fig. 1. Process of locating and selecting articles

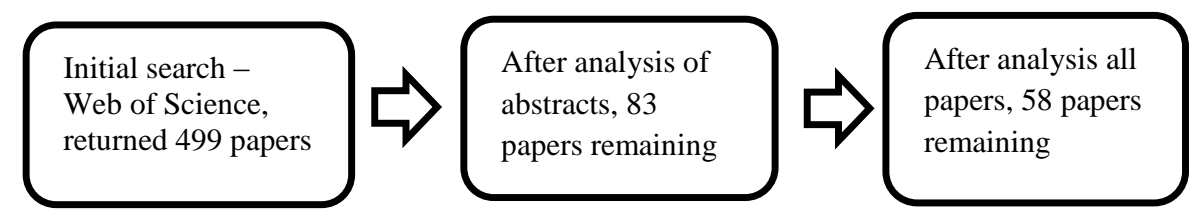

\subsection{Analysis and Synthesis}

After selecting the most appropriate journal papers and conference proceedings for the purpose of this study, the papers were analysed and synthesised in two stages. The aim of the analysis is to examine and dissect different studies and identify the relationships between the elements [9]. Furthermore, synthesis is the integrating stage-to group the results of various studies "into a new or different arrangement and developing knowledge that is not apparent from reading the individual studies in isolation" [9]. The first stage is to concentrate on the categorisation of studies according to the criteria shown in Table 2. The second stage is to focus on how to identify and synthesize the main contributions of the identified publications to answer the research questions.

Table 2. Criteria for quantitative analysis of the papers [53]

\begin{tabular}{|c|c|}
\hline Criterion & Type of analysis \\
\hline Publication date & Verification of the timeliness of the theme \\
\hline Publication source & $\begin{array}{l}\text { Papers must be published in peer-reviewed journals and conference } \\
\text { proceedings }\end{array}$ \\
\hline Location & $\begin{array}{l}\text { Analysis of the geographical dispersion of the papers based on the } \\
\text { location of the authors }\end{array}$ \\
\hline Methodology used & $\begin{array}{l}\text { Analysis of the classification of articles and the approaches used in the } \\
\text { studies }\end{array}$ \\
\hline
\end{tabular}

\section{Characteristics of Publications}

In this section, we present an overview of the main information of the 58 articles identified related to the risk sources and resilience factors in agri-food supply chains. The analysis of the publication date, publication source, methodology used and authors' affiliation are all aims at showing the context of the literature regarding the relationship between the themes of risk sources and resilience factors in agri-food supply chains. The identified publications will be analysed quantitatively.

\subsection{Date of Publication}


Figure 2 shows that a small fluctuation happened from 2000 to 2014, and then there has a big increase in publications of risk sources and resilience factors in agri-food supply chain from 2014 to 2016 . The Figure 2 also shows that there has been a small increase in publications in 2008. We assumed that the economic crisis between 2007 and 2009 encouraged researchers to do more on agri-food supply chain resilience. Most of publications were published between 2013 and 2016, which account for $52 \%$ of all identified publications. As a result, this study has been conducted in the early 2017, and we expect the number of publications in 2017 would surpass that in 2015 and 2016. The increase in publications indicates that researchers and practitioners have been more aware of the importance of risk sources and resilience factors in agrifood supply chains.

Fig. 2. Year-wise distribution of publications

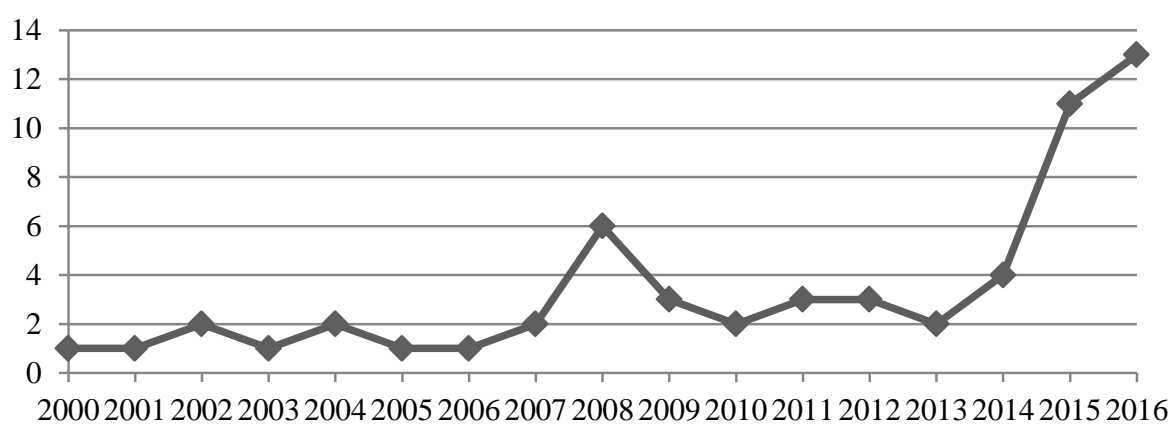

\subsection{Publication Source and Methodology Used in the Papers}

The papers have been published in 36 different journals mainly in Supply Chain Management: An International Journal (5), British Food Journal (3) and European Journal of Operational Research (3). As for the research methodology used in the papers, 19 papers used case study and 20 papers used empirical study. 12 of 58 papers used literature review as their research methodology, whereas only seven papers are conceptual study. It indicates that academic researchers and practitioners are less interested in conceptual studies in the area of risk sources and resilience factors in the agri-food supply chain.

\subsection{Location}

Figure 3 shows that the authors come from 22 countries, which demonstrated that risk sources and resilience factors in agri-food supply chain attracted global interest. Although there are a large number of articles written by authors from Australia, the number of papers from Europe, Asia and Middle East is also significant. 
Fig. 3. Author's affiliation

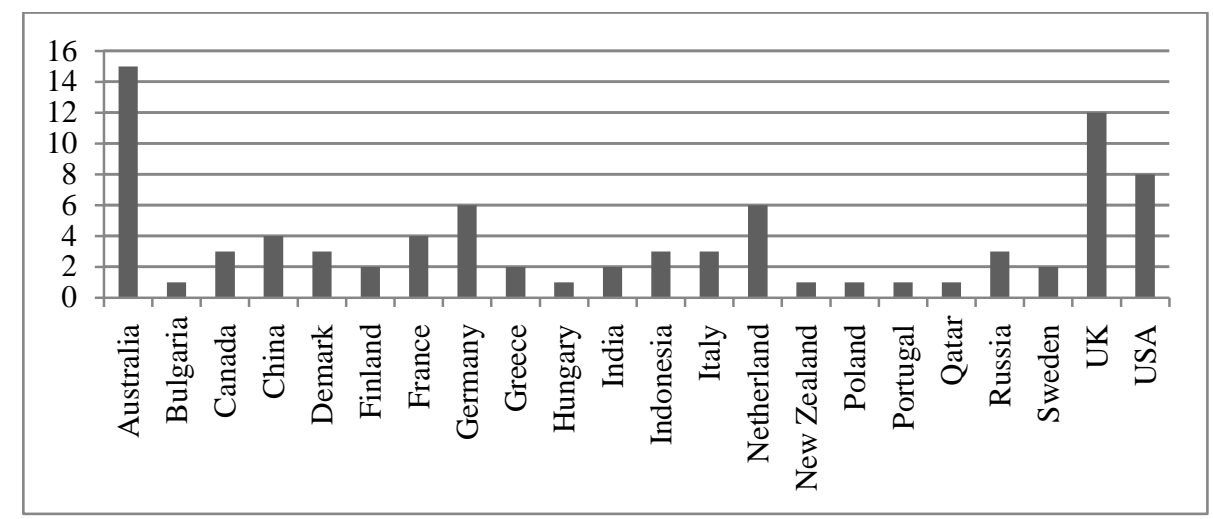

\section{Risk Sources in Agri-food Supply Chains}

In previous studies, there are various methods to classify risk sources in supply chains. Based on the reviewed literature, risk sources can be divided into internal risk sources and external risk sources [50]. Within these two groups, it is not difficult to find that there are a number of common risk sources existing in almost any supply chains, as well as specific risk sources for agri-food supply chains [49]. These specific risk sources result from the specific attributes of agri-food supply chains, such as perishable characteristics of products and the rigid time constraints [47]. In the following, we will conduct a detailed analysis of specific risk sources existing in agrifood supply chains.

\subsection{Antibiotic Resistance}

Antibiotic resistance is emerging as a serious problem in food production sector, while clinical uses and misuses of antibiotics intensify the crisis [3]. Using antibiotics in food production not only broaden the role of agri-food supply chain just as a dispersal route for resistant bacteria and resistance genes, but also as an incentive for the sharing of resistance genes through horizontal gene transfer [20]. Resistant bacteria not only can cause contamination during the processing food products, but also can increase transmission route between humans [3]. The final result of the spread of resistant bacteria through food production is that human may be directly exposed to various bacteria from farmed animals [3]. International food standards highlight that it is necessary to consider the selecting and disseminating of foodborne resistance in food production risk analysis.

\subsection{Weather-related Risks and Natural Disasters}


Natural disasters can affect agri-food supply chains for several growing seasons. These risks normally cause the following results: short-term food productions reduce, food price increases, infrastructure destruction that impedes the goods transportation, information diffuse, service provided. Smith et al. [40] conducted a case study of flooding risk in Australia's food supply chains. They find that besides the damage to crops and farmland, more serious impact is on food delivery, which means that food cannot be delivered through normal routes. In some cases, flooding increases another $1000 \mathrm{~km}$ compared to the usual trip. Carter and Rogers [6] find that conservation tillage practices will be influenced by the drought risks in the following few years. Weather-related risks (such as hail, strong wind and excess rain) can cause pests and diseases outbreaks subsequently. Smit et al. [39] proposed that the selection of appropriate corn seed was affected by the weather conditions in the last few years. Along with this route, Finger and Lehmann [15] find that farmers will increase investment in hail insurance after experiencing a hail event.

\subsection{Policy and Institutional Risks}

Policy and institutional risks have various impacts on agri-food supply chains. For example, these risks may alter the structure of the agri-food supply chains, may increase food product quality of agri-food supply chains, and may change the relationship among the agri-food supply chain members. Mittenzwei et al. [29] investigate the policy uncertainty in the agriculture sector in Norway. They find that $67 \%$ of farm in Norway are affected by market price support policy and subsidies from the government, which is a large proportion compared to other countries. The heavily relying on subsidies of farm income in Norway form a potential source of uncertainty as policies, in principle, may be changed frequently.

\subsection{Unethical Issues in Agri-food Supply Chains}

Several authors have conducted research on unethical practices that can cause supply chain uncertainty. For example, Christopher and Peck [7] proposed that tangible supply chain cost increase will be caused by unethical business practice, such as monitoring business transactions and expenses on lobbying governments to update policies. Gonzalez [18] separately examined that unethical behaviour may help the firm to acquire profits but can cause expense on the whole supply chain. After collecting data from four focal manufacturers, four first-tier suppliers and four firsttier customers in Indonesian food industry, Simangunsong et al. [36] observed three unethical practices that can cause supply chain uncertainty in the food supply chain. First, collusion among suppliers of the same product, which involves the timing and pricing of supplies for the purchasing organisation. Second, organisations may seek chance to impact food policies so that the competitors may have to recall their products or packaging, whereas the organisation's own product or packing remains within regulations. Finally, anti-competition behaviour has been observed among large food retailers. 


\section{Resilience Factors in Agri-food Supply Chains}

This section will demonstrate the major enablers of supply chain resilience first (Table 3), and then summarise the major resilience factors exist in the agri-food supply chain according to our literature review.

Table 3. Resilience factors in agri-food supply chain

\begin{tabular}{|c|c|c|}
\hline Resilience enablers & Description & $\begin{array}{r}\text { Supporting } \\
\text { literatures }\end{array}$ \\
\hline Agility & $\begin{array}{l}\text { Agility is defined as "the ability of a supply } \\
\text { chain to rapidly respond to change by } \\
\text { adapting its initial stable configuration" [51]. }\end{array}$ & [14], [7] \\
\hline $\begin{array}{l}\text { Collaboration among } \\
\text { suppliers }\end{array}$ & $\begin{array}{l}\text { Pettit et al. [30] define supply chain } \\
\text { collaboration as "the ability to work } \\
\text { effectively with other entities for mutual } \\
\text { benefits". }\end{array}$ & {$[21],[32],[2]$} \\
\hline $\begin{array}{l}\text { Risk and revenue } \\
\text { sharing }\end{array}$ & $\begin{array}{l}\text { "Risk and revenue sharing is a kind of supply } \\
\text { chain contract which makes it possible to } \\
\text { share risks among supply chain partners" [43]. }\end{array}$ & [43] \\
\hline Trust & $\begin{array}{l}\text { "Trust is generally seen as a precondition for } \\
\text { risk sharing" [38]. }\end{array}$ & {$[28],[12]$} \\
\hline Visibility & $\begin{array}{l}\text { Francis [17] defined visibility as "the identity, } \\
\text { location and status of entities transiting the } \\
\text { supply chain, captured in timely messages } \\
\text { about events, along with the planned and } \\
\text { actual dates/times of these events". }\end{array}$ & {$[41],[38],[7]$} \\
\hline Sustainability & $\begin{array}{l}\text { "Sustainability is important for maintaining a } \\
\text { value, awareness, society, and business } \\
\text { reputation as well as enhancing a business } \\
\text { environment and cooperation along a supply } \\
\text { chain" [11]. }\end{array}$ & {$[10],[28]$} \\
\hline Adaptive capability & $\begin{array}{l}\text { The adaptive capacity involved three phases, } \\
\text { which are readiness, responsiveness and } \\
\text { recovery [37]. }\end{array}$ & [41] \\
\hline $\begin{array}{l}\text { Knowledge management } \\
\text { and supply chain } \\
\text { structure }\end{array}$ & $\begin{array}{l}\text { "Knowledge and understanding of supply } \\
\text { chain structures-both physical and } \\
\text { informational-are important elements of } \\
\text { supply chain resilience" [31]. }\end{array}$ & [7], [4] \\
\hline Traceability & $\begin{array}{l}\text { "Traceability is the ability to trace and track } \\
\text { food, and food ingredients through the supply } \\
\text { chain; thus, all stages of production, } \\
\text { processing and distribution" [48]. }\end{array}$ & [46], [28], [48] \\
\hline Flexibility/Redundancy & $\begin{array}{l}\text { Having multiple suppliers, multiple } \\
\text { transportation channels, flexible supply base } \\
\text { are examples can help to increase supply } \\
\text { chain resilience [37]. }\end{array}$ & $\begin{array}{r}{[7],[31],[37],} \\
{[21]}\end{array}$ \\
\hline $\begin{array}{l}\text { Supply chain risk } \\
\text { management culture }\end{array}$ & $\begin{array}{l}\text { "Culture of risk management should extend } \\
\text { beyond the boundaries of corporate risk and } \\
\text { business continuity management" [7]. }\end{array}$ & [7], [50] \\
\hline
\end{tabular}




\subsection{Traceability}

Traceability refers to the ability to trace and track food and food ingredients in agrifood supply chains or trace and track food in three stages: food production, processing and distribution [48]. Several authors indicate to adopt food traceability in agri-food supply chain have various advantages. First, food traceability has an important role in recalling contaminated products and hindering counterfeited products from reaching the market [46]. Second, applied integrated traceability systems can improve recall efficiency, supply chain transparency, inventory and revenues; more importantly, it can help to increase customer trust on food safety [28]. Third, food traceability has a positive effect on monitoring food characteristics.

Supply chain visibility has some similar function with traceability such as monitor the supply chain in real time. Pettit et al. [30] defined visibility as "the knowledge of the status of operating assets and the environment". No matter which term is used, traceability or visibility, they both are all heavily rely on close collaboration between suppliers and customers, are all heavily rely on investment in information sharing [7], [42].

\subsection{Inter-organisational Knowledge Management}

Through systematic literature review, we find that knowledge management is an important construct in supply chain resilience due to frequent cited reference to knowledge management practices [4], [7]. After collecting data from nine VOAD lead member organisations, Scholten et al. [35] examined that horizontal and vertical collaboration, risk awareness, supply chain reengineering and knowledge management constitute the foundation of supply chain resilience. Esper et al. [10] suggest that creating customer value need supply chain members to integrate demand process and supply process through inter-organisational knowledge management. They also highlight that knowledge-sharing capabilities has a positive effect on supply chain cost reduction, and supply chain cost reduction influence supply chain resilience. Lingegard and Lindahl [23] did a survey from customer's side and supplier's side separately. They find that inter-organisational knowledge transfer not only can produce profits, but also play an important role in reducing environmental impact and increasing cost efficiency and quality. Except for these authors, other researchers also did a lot of research in inter-organisational knowledge management. For example, knowledge sharing has a positive effect on market orientation strategy, increase customer satisfaction and level of service between logistics service provider and customer [33], [1].

\subsection{Supply Chain Collaboration}

While agri-food supply chains are extended across the globe, it is obvious that agrifood supply chains become longer than before [21]. The unique characteristics of agri-food products require that the agri-food supply chain maintains the food quality across the whole process from initial production to end customers [29]. Therefore, a 
high level of collaboration among agri-food supply chain entities is necessary [30], [12]. Cao et al. [5] defines collaboration as "the collaborative activities of information sharing, goal congruence, joint decision making, resource sharing, incentive alignment, collaborative communication and joint knowledge creation among independent supply chain partners". Scholten and Schilder [34] proposed that supply chain collaboration reduces the impact of disruption through building the same goal and presenting clearly business needs. Through exploring Australian citrus supply chains, Ali and Shukran [2] find that long-term relationships between supply chain members could be better able to deal with divergent risks such as price fluctuation, opportunism, high operational costs, and behavioural uncertainties. Prima Dania et al. [32] conducted a literature review about collaboration and sustainability in agri-food supply chains. They find that vertical collaboration, horizontal collaboration and mixed vertical and horizontal collaboration have a positive effect on agri-food supply chain in term of mitigating environment impacts as well as to achieve socio-economic development. Leat and Revoredo-Giha [22] also find that vertical collaboration and horizontal collaboration in supply chain members can facilitate supply chain risk management after they have an in-depth investigation on ASDA Porklink supply chain in Scotland. After conducting 16 semi-structured interviews in food processing industry, Pettit et al. [30] concluded that information sharing, collaborative communication, mutually created knowledge and joint relationship efforts play important roles in increasing agri-food supply chain resilience. An empirical study conducted by Manos et al. [26] revealed that while collaboration in the daily operation is necessary for supply chain collaboration, the structure of the agri-food supply sector along with the attribute of products impinges the intensity of collaboration, to more operational and tactical level, as well as, to logistics-related activities. They also find that the intensity of collaboration can be seriously affected by trust. Finally, Soni et al. [42] use an interpretive structural modelling approach to analysis all major enablers of supply chain resilience. They find that supply chain collaboration is ranked second among fourteen enablers of supply chain resilience.

\subsection{Supply Chain Risk Management Culture}

In today's unstable business environment, it is very important to have a risk perception for an organisation. Christopher and Peck [7] highlighted that supply chain risk management culture is a critical element for organisation to develop a resilient organisation. Sheffi [37] pointed out that culture has an important impact for an organisation to survive from supply chain disruptions. Manning and Mei Soon [25] conducted a literature review on strategic resilience in the food supply chain, where they find that culture has a positive effect when organisations face food fraud issues. Vlajic et al. [49] refers that risk management culture is indispensable for an organisation. Smith [41] point out that risk management culture, agility, collaboration and visibility, all have a positive effect on supply chain resilience. Finally, Christopher et al. [8] argued that there are two most common approaches to global sourcing risk mitigation, one is risk management culture, and the other is global sourcing reengineering. 


\subsection{Agility}

Agility is defined as "a strategic ability that assists organisational rapidly to sense and respond to internal and external uncertainties via effective integration of supply chain relationships" [14]. Soni et al. [42] think agility is the most important one among 14 enablers of supply chain resilience. Sullivan-Taylor and Branicki [44] use organisational theory to explore resilience factors in SMEs, where they find that agility was regarded as an important capability which has received great support among 11 SMEs decision makers.

\section{Discussion}

By being aware of resilience factors and risk sources identified in the literature, an agri-food supply chain entity can modify their organisational resilience factors easily according to generate balanced resilience (Figure 4). In this context, risk sources will either be tackled completely or offset to a controllable level by an organisations capability to adapt. Furthermore, we can imagine that daily operations will be more efficient and effective as a result of the continuous process of tweaking resilience factors to meet unstable agri-food supply chains. On the other hand, unbalanced situation between resilience factors and risk sources which is easily to meet in day to day operations. For example, excessive resilience factors compared to risk sources can erode revenue. Likewise, if more profit is invested in building supply chain risk management culture, it is possible to return to a situation where traceability system becomes dated. This will result agri-food supply chain in a high risk state which will cause high consequences events occurring.

Fig. 4. The balance between resilience factors and risk sources

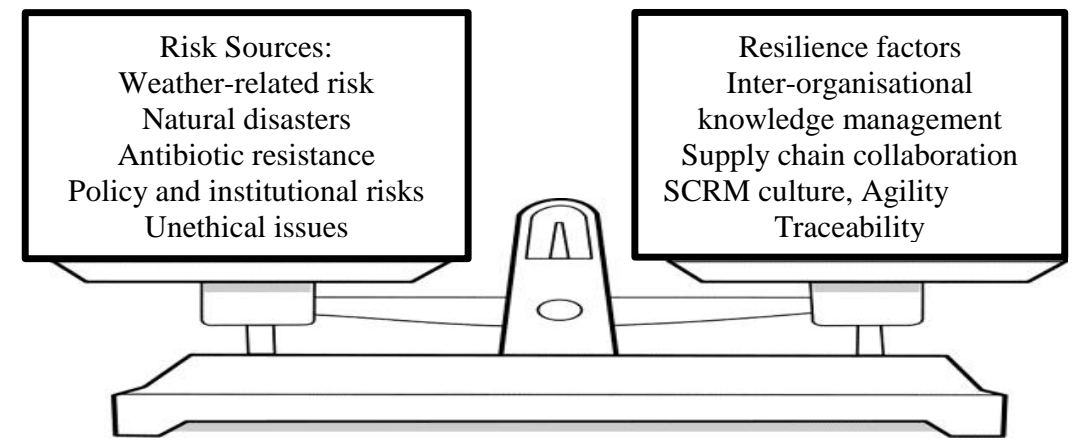

\section{Conclusions}

In this study, we conducted a systematic literature review to identify risk sources and resilience factors in agri-food supply chains. Through this process, we identified 58 
publications, the majority of them are journal papers, a minority of them are conference proceedings. Main risk sources identified from the literature include unethical issues, antibiotic resistance, policy and institutional risks as well as weather related risks and natural disasters. At a supply chain level some of the risks are partially controllable, for example, unethical issues and institutional risks, but this also depends on the level of agri-food supply chain integration and collaboration. In addition, more empirical studies are needed to have a deep understanding of the damage of antibiotic resistance and unethical issues to agri-food supply chains. As for resilience factors in agri-food supply chain, literature has widely discussed are traceability, inter-organisational knowledge management, supply chain collaboration, supply chain risk management culture and agility. Although some of the resilience factors have been widely discussed in agri-food supply chains, the relationship between several key factors of agri-food supply chain resilience is not well understood. For example, the literature is not clear on whether there is a relationship between inter-organisational knowledge management and traceability. Also, there is little insight into the dynamics and development of traceability, and how traceability can enhance supply chain resilience in agri-food supply chains. Future work will investigate relationships between the risk sources and resilience factors, in order to develop a framework for agri-food supply chains.

\section{References}

1. Abid, M., Ali, B.: Antecedents and effectiveness of CKM: an empirical study. J. Basic and Applied Sci. Res. 4, 104--117(2014)

2. Ali, I., Shukran, K.: Management supply chain risks and vulnerabilities through collaboration: present and future scope. J. Developing Areas 50, 335--342(2016)

3. Bengtsson-Palme, J.: Antibiotic resistance in the food supply chain: where can sequence and metagenomics aid risk assessment? Current Opinion in Food Sci. 14, 66--71(2017)

4. Blackhurst, J et al.: An empirically derived framework of global supply resiliency. J. Bus. Logist. 32, 374-391(2011)

5. Cao, $\mathrm{M}$ et al.: Supply chain collaboration: conceptualization and instrument development. Int. J. Prod. Res. 48, 6613--6635(2010)

6. Carter, C.R., Rogers, D.S.: A framework of sustainable supply chain management: moving toward theory. Int. J. Phys. Distrib. Logist. Manag. 38, 360--387(2008)

7. Christopher, M., Peck, H.: Building the resilient supply chain. Int. J. Logist. Manag. 15, $1--13(2004)$

8. Christopher, $\mathrm{M}$ et al.: Approaches to managing global sourcing risk. Supply Chain Manag.: Int. J. 16, 67--81(2011)

9. Denyer, D., Tranfield, T.: The Sage Handbook of Organisational Research Methods. Sage, London (2009)

10. Esper, $\mathrm{T}$ et al.: Demand and supply integration: a conceptual framework of value creation through knowledge management. J. of the Academy of Marketing Sci. 38, 5--18(2010)

11. Faisal, M.N.: Sustainable supply chains: a study of interaction among the enablers. Bus. Process. Manag. J. 16, 508--529(2010)

12. Faisal, M.N. et al.: Supply chain risk mitigation: modelling the enablers. Bus. Process. Manag. J. 12, 535--552(2006)

13. Faisal, M.N. et al.: Information risks management in supply chains: an assessment and mitigation framework. J. Enterp. Inf. Manag. 20, 677--699(2009) 
14. Fayezi, $\mathrm{S}$ et al.: Understanding and development of supply chain agility and flexibility: a structural literature review. Int. J. Manag. Rev. 00, 1--30(2016)

15. Finger, R., Lehmann, N. The influence of direct payments on farmers, hail insurance decisions. Agri. Econ. 43, 343--354(2012)

16. Fraizer, G.I. et al.: Just-in-time exchanage relationships in industrial markets. J. Marketing. 52, 52--67(1988)

17. Francis, V.: Supply chain visibility: lost in translation? Supply Chain Manag: Int. J. 13, 180--184(2008)

18. Gonzalez, C.: Climate change, food security, and agrobiodiversity: toward a just, resilient, and sustainable food system. Fordham Environ Law Rev. 22, 11--19(2011)

19. Hong, Y and Choi, T.Y.: Unveiling the structure of supply networks: Cases in Honda, Acura and Daimler Chrysler. J. Oper. Manag. 20, 469--493(2002)

20. Johnson, TA et al.: Clusters of antibiotic resistance genes enriched together stay together in swine agriculture. mBio 7, e02214--15(2016)

21. Kamalahmadi, M,. Mellat Parast, M.: A review of the literature on the principles of enterprise and supply chain resilience: Major findings and directions for future research. Int.

J. Prod. Res. 171, 116--133(2016)

22. Leat, P., Revoredo-Giha, C.: Risk and resilience in agri-food supply chains: the case of the ASDA PorkLink supply chain in Scotland. Supply Chain Manag.: Int. J. 18, 219-231(2013)

23. Lingegard, S., Lindahl, M. 2015. Integrated product service offering for rail infrastructure benefits and challenges regarding knowledge transfer and cultural change in a Swedish case.

J. Cleaner. Prod. 98, 166--174(2015)

24. Macfadyen, $S$ et al.: The role of food retailers in improving resilience in global food supply. Global Food Security 7, 1--8(2015)

25. Manning, L., Mei Soon, J.: Building strategic resilience in the food supply chain. British Food J. 118, 1477--1493(2016)

26. Manos, B et al.: A conceptual framework for supply chain collaboration: empirical evidence from the agri-food industry. Supply Chain Manag.: Int. J. 12, 177--186(2007)

27. Melnyk, S.A. et al.: Understanding supply chain resilience. Supply Chain Manag. Rev. 18, 34--41(2014)

28. Meuwissen, M.P.M. et al.: Certification in meat supply chains. J. of Agribusiness 21, $167--$ 181(2003)

29. Mittenzwei, K et al.: Combined effects of climate change and policy uncertainty on the agricultural sector in Norway. Agri. Syst 153, 118--126(2017)

30. Pettit, T.J. et al.: Ensuring supply chain resilience: development of a conceptual framework. J. Bus. Logist. 31, 1--21(2010)

31. Ponomarov, S.Y., Holcomb, M.C.: Understanding the concept of supply chain resilience. Int. J. Logist. Manag. 20, 124--143(2009)

32. Prima Dania, W.A. et al.: Collaboration and sustainable agri-food supply chain: a literature review. MATEC Web of Conferences. In: 3rd Bali International Seminar on Sciences \& Technology. EDP Sciences, Les Ulis (2016)

33. Rollins, $M$ et al.: Inter-firm customer knowledge sharing in logistics services: an empirical study. Int. J. Phys. Distrib. Logist. Manag. 41, 956--971(2011)

34. Scholten, K., Schilder, S.: The role of collaboration in supply chain resilience. Supply Chain Manag.: Int. J. 20, 471--484(2015)

35. Scholten, K et al.: Mitigation process - antecedents for building supply chain resilience. Supply Chain Manag.: Int. J. 19, 211--228(2014)

36. Simangunsong, E et al.: Managing supply chain uncertain with emerging ethical issues. Int. J. Oper. Prod. Manag. 36, 1272--1307(2016) 
37. Sheffi, Y.: Preparing for the big one. IEE Manuf. Eng. 84, 12--15(2005)

38. Sheffi, Y.: Supply chain management under the Threat of International Terrorism. Int. J. Logist. Manag. 12, 1--11(2001)

39. Smit, B et al.: Corn hybrid selection and climatic variability: gambling with nature? The Canadian Geographer 41, 429--438(1997)

40. Smith, K et al.: The resilience of long and short food chains: a case study of flooding in Queensland, Australia. Agri. Human Values 33, 45--60(2016)

41. Smith, R.: Operational capabilities for the resilient supply chain. Supply Chain Pract. 6, 24$-35(2004)$

42. Soni, U et al.: Measuring supply chain resilience using a deterministic modelling approach. Comput. Ind. Eng. 74, 11--25(2014)

43. Spekman, R.E. et al.: An empirical investigation into supply chain management: A perspective on partnerships. Supply Chain Manag.: Int. J. 3, 53--67(1998)

44. Sullivan-Taylor, B., Branicki, B.: Creating resilient SMEs: why one size might not fit all. Int. J. Prod. Res 49, 5565--5579(2011)

45. Tendall, D.M. et al.: Food system resilience: Defining the concept. Global Food Security 6, $17--23(2015)$

46. Thakur, M., Hurburgh, C.R.: Framework for implementing traceability in the bulk grain supply chain. J. Food Eng. 95, 617--626(2009)

47. van der Vorst, J.GA.J., Beulens, A.J.M.: Identifying sources of uncertainty to generate supply chain redesign strategies. Int. J. Phys. Distrib. Logist. Manag. 32, 409--430(2002)

48. van Rijswijk, W., Frewer, L.J.: Consumer perceptions of food quality and safety and their relation to traceability. British Food J. 110, 1034--1046(2008)

49. Vlajic, J.V. et al.: A framework for designing robust food supply chain. Int. J. Prod. Econ. 137, 176--189(2012)

50. Waters, D.: Supply Chain Risk Management: Vulnerability and Resilience in Logistic Kogan Page Limited, London (2007)

51. Wieland, A., Wallenburg, C.M.: The influence of relational competencies on supply chain resilience: a relational view. Int. J. Phys. Distrib. Logist. Manag. 43, 300--320(2013)

52. Xiaoping, W.: Food Supply Chain Safety Risk Evaluation Based on AHP Fuzzy Integrated Evaluation Method. Int. J. Security and Its Applications 10, 233--244(2016)

53. Zimmermann, R. et al.: The influence of supply chain on the innovation process: a systematic literature review. Supply Chain Manag.: Int. J. 21, 289--304 (2016) 